\title{
Effect of hepatitis C serology on C-reactive protein in a cohort of Brazilian hemodialysis patients
}

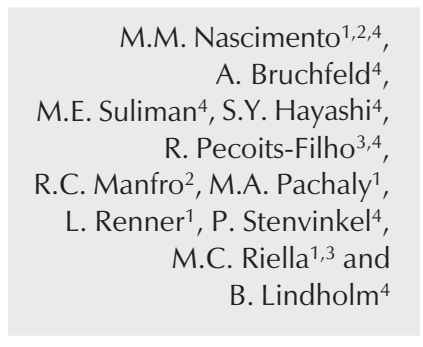

Correspondence

M.C. Riella

Pós-Graduação em Ciências da Saúde PUC do Paraná

Bruno Filgueira, 369, 17ㅇandar

80240-220 Curitiba, PR

Brasil

Fax: +55-41-342-5849

E-mail: mcriella@pro-renal.org.br

Research supported by Karolinska Institute, Stockholm, Sweden, and by a grant from Baxter Healthcare Corporation, Deerfield, IL, USA. M.M. do Nascimento was the recipient of a CAPES fellowship (No. BEX0291/02).

Received April 16, 2004 Accepted March 4, 2005

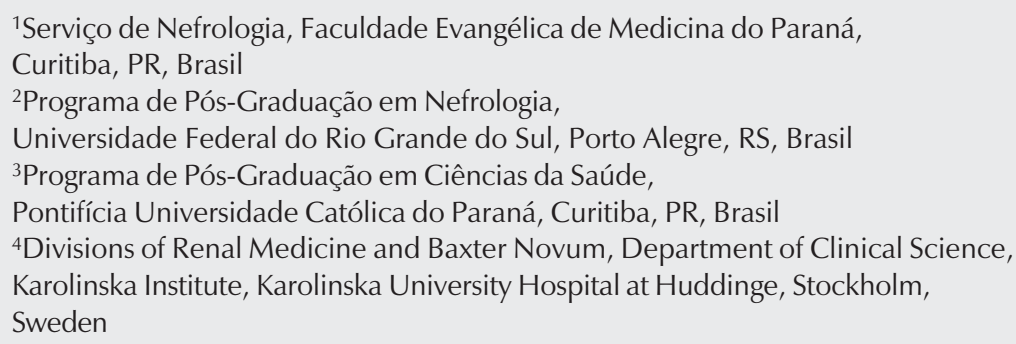

'Serviço de Nefrologia, Faculdade Evangélica de Medicina do Paraná, Curitiba, PR, Brasil

2Programa de Pós-Graduação em Nefrologia,

Universidade Federal do Rio Grande do Sul, Porto Alegre, RS, Brasil

${ }^{3}$ Programa de Pós-Graduação em Ciências da Saúde,

Pontifícia Universidade Católica do Paraná, Curitiba, PR, Brasil

${ }^{4}$ Divisions of Renal Medicine and Baxter Novum, Department of Clinical Science, Karolinska Institute, Karolinska University Hospital at Huddinge, Stockholm, Sweden

\section{Abstract}

Hepatitis $\mathrm{C}(\mathrm{HCV})$ is not an uncommon feature in hemodialysis (HD) patients and may be a cause of systemic inflammation. Plasma cytokine interleukin-6 (IL-6) is mainly produced by circulating and peripheral cells and induces the hepatic synthesis of C-reactive protein (CRP), which is the main acute phase reactant. The aim of this study was to investigate the influence of HCV on two markers of systemic inflammation, serum CRP and IL-6, in HD patients. The study included 118 HD patients (47\% males, age $47 \pm 13$ years, 9\% diabetics) who had been treated by standard HD for at least 6 months. The patients were divided into two groups depending on the presence $(\mathrm{HCV}+)$ or absence ( $\mathrm{HCV}$-) of serum antibodies against HCV. Serum albumin (S-Alb), plasma high sensitivity CRP (hsCRP), IL-6, and alanine aminotransferase (ALT) were measured and the values were compared with those for 22 healthy controls. Median hsCRP and IL-6 values and hsCRP/IL-6 ratio were: 3.5 vs $2.1 \mathrm{mg} / \mathrm{l}$, $\mathrm{P}<0.05 ; 4.3$ vs $0.9 \mathrm{pg} / \mathrm{ml}, \mathrm{P}<0.0001$, and 0.8 vs $2.7, \mathrm{P}<0.0001$, for patients and controls, respectively. Age, gender, S-Alb, IL-6 and hsCRP did not differ between the $\mathrm{HCV}+$ and $\mathrm{HCV}$ - patients. However, HCV+ patients had higher ALT $(29 \pm 21$ vs $21 \pm 25 \mathrm{IU} / \mathrm{l})$ and had been on HD for a longer time $(6.1 \pm 3.0$ vs $4.0 \pm 2.0$ years, $\mathrm{P}<$ $0.0001)$. Moreover, $\mathrm{HCV}+$ patients had a significantly lower median hsCRP/IL-6 ratio (0.7 vs 0.9, $\mathrm{P}<0.05)$ compared to the $\mathrm{HCV}$ - group. The lower hsCRP/IL-6 ratio in $\mathrm{HCV}+$ patients than in $\mathrm{HCV}$ - patients suggests that hsCRP may be a less useful marker of inflammation in $\mathrm{HCV}+$ patients and that a different cut-off value for hsCRP for this population of patients on HD may be required to define inflammation.
Key words

- Hepatitis C

- C-reactive protein

- Interleukin-6

- Hemodialysis 


\section{Introduction}

Hepatitis C virus (HCV) is a common problem in patients with chronic kidney disease (CKD) $(1,2)$. In Brazil the prevalence of $\mathrm{HCV}$ antibodies in hemodialysis (HD) patients is as high as 20-50\%, depending on the region (3). The course of HCV may extend over decades in non-uremic patients, but in $\mathrm{HD}$ patients the long-term follow-up of $\mathrm{HCV}$ infected patients is limited due to elevated morbidity and mortality (4).

C-reactive protein (CRP) is an independent predictor of mortality in HD patients $(5,6)$. CRP expression in vivo is assumed to be restricted mainly to the liver (7) where $\mathrm{CRP}$ is produced under the control of various pro-inflammatory cytokines such as interleukin 1 (IL-1), IL-6 and tumor necrosis factor $\alpha(\mathrm{TNF}-\alpha)(8)$. IL-6 is the prototypic pleiotropic cytokine commonly produced at local tissue sites, and circulating receptors modulate the biological effects of cytokines (9). The IL-6 receptor consists of two units: a ligand-binding part (gp-80) and a signal transducing part (gp-130) (10). High levels of IL-6 and its soluble receptor are present in cirrhotic as well as CKD patients (9,11-13). Nevertheless, there are few reports describing the CRP response to increased plasma IL-6 levels in $\mathrm{HCV}+$ renal patients.

In response to various stimuli such as uremia, $\mathrm{HCV}$ infection, and HD itself, naive CD4- $\mathrm{T}$ cells differentiate into effector $\mathrm{T}$ helper (Th) cells and, according to the pattern of cytokine production, two $\mathrm{T}$ subsets of cells have been defined: Th1 cells, which produce interferon gamma and IL-2, and Th 2 cells, which produce IL- 4 and IL- 10 and other cytokines such as IL-6 (14,15). A predominance of Th1 cytokine expression has been observed in patients with CKD, but it is not known if this imbalance could affect the production of CRP in the liver, especially in HD patients with liver injury such as hepatitis C.

The purpose of the present study was to investigate if $\mathrm{HD}$ patients with serological evidence of $\mathrm{HCV}(\mathrm{HCV}+)$ have different levels of high sensitivity CRP (hsCRP), IL-6 and hsCRP/IL-6 ratio compared to HD patients without serological evidence of $\mathrm{HCV}$ (HCV-).

\section{Subjects and Methods}

\section{Patients and study design}

A total of $118 \mathrm{HD}$ patients (56 males; median age, 47 years; range, 16-89 years) treated at three dialysis centers in the city of Curitiba (PR, Brazil) were enrolled in the study. The main inclusion criterion was HD treatment for at least 6 months. Patients with chronic inflammatory disease, i.e., rheumatic diseases, and active infection as well as hepatitis B, defined by the serum detection of HBs antigen, were excluded from the study. The causes of renal failure were as follows: chronic glomerulonephritis $(\mathrm{N}=54)$, hypertensive nephrosclerosis $(\mathrm{N}=32)$, diabetic nephropathy $(\mathrm{N}=13)$, and other causes $(\mathrm{N}$ =19). All patients were hemodialyzed three times weekly with modified cellulose membranes (cellulose acetate or derived cellulose). None of the patients had been treated with antiviral agents such as interferon or ribavirin. Twenty-two healthy controls were used for comparative analysis. The Ethics Committee of Hospital Evangélico de Curitiba approved the study protocol and all subjects gave written informed consent to participate in the study.

\section{Biochemical analysis}

HD patients were investigated during a mid-week session before dialysis. Venous blood samples were collected from the HD patients and control subjects in the morning after an overnight fast. Plasma was separated from blood cells and stored at $-70^{\circ} \mathrm{C}$ until the time for analysis. Serum albumin (SAlb) was determined by the bromocresol 
green method. Plasma hsCRP and alanine transferase were measured by the nephelometry method. Plasma IL-6 levels were measured by ELISA (Ortho, Raritan, NJ, USA). The diagnosis of hepatitis $\mathrm{C}$ was made based on the detection of anti-HCV antibodies by the anti-HCV test using second-generation ELISA (ELISA-2; Ortho) based on six consecutive measurements performed monthly before the beginning of the study.

\section{Statistical analysis}

Data are reported as means $\pm \mathrm{SD}$, or median and range as appropriate. A P value below 0.05 was considered to be significant. Comparisons between two groups were performed by the Student $t$-test for normally distributed variables, whereas the MannWhitney U-test was used for non-normally distributed variables. Categorical variables were analyzed using contingency tables. For non-normally distributed variables, correlations were calculated using the Spearman rank test. Log values of hsCRP and IL-6 were used for univariate regression analysis.

\section{Results}

\section{Clinical and laboratory data for HD and controls}

The clinical characteristics of HD patients and healthy controls are given in Table 1. In HD patients, a significant negative correlation was found between S-Alb and hsCRP (Rho $=-0.21, \mathrm{P}<0.05$ ). Positive correlations were found between IL- 6 and age $($ Rho $=0.38, P<0.0001)$ and IL-6 and hsCRP $(\mathrm{Rho}=0.48, \mathrm{P}<0.0001)$, whereas an inverse correlation was found between IL-6 and S-Alb (Rho $=-0.20, \mathrm{P}<0.01)$. On the other hand, no significant correlation was found between hsCRP and age ( $\mathrm{Rho}=0.13$, $\mathrm{P}=0.15)$. Whereas a significant negative correlation was found between hsCRP/IL-6 and alanine transferase $(\mathrm{Rho}=-0.23, \mathrm{P}=$
0.01), no significant correlations were found between the hsCRP/IL- 6 ratio and age or time on dialysis, respectively.

\section{Comparisons of patients according to HCV serology}

The basal clinical and laboratory characteristics of the two groups are listed in Table 2. Sixty-two patients had anti-HCV antibodies. As expected, the mean time on HD treatment was significantly increased in the $\mathrm{HCV}+$ group $(6 \pm 3$ years) compared to the HCV- group $(4 \pm 2$ years, $\mathrm{P}<0001)$. The median level of serum hsCRP $(\mathrm{mg} / \mathrm{l})$ was lower in the $\mathrm{HCV}+$ group than in the HCV-

Table 1. Clinical and biochemical characteristics of patients on hemodialysis and healthy controls.

\begin{tabular}{|c|c|c|}
\hline & HD patients $(\mathrm{N}=118)$ & Controls $(\mathrm{N}=22)$ \\
\hline Age (years) ${ }^{a}$ & $47 \pm 13$ & $32 \pm 9^{*}$ \\
\hline Male gender (\%) & 47 & 50 \\
\hline Diabetes mellitus (\%) & 11 & - \\
\hline hsCRP $\left(\mathrm{mg} / \mathrm{ll}^{\mathrm{b}}\right.$ & $3.5(0.2-150)$ & $2.1(0.1-7.8)^{*}$ \\
\hline $\mathrm{IL}-6(\mathrm{pg} / \mathrm{ml})^{\mathrm{b}, \mathrm{c}}$ & $4.3(0.9-19.6)$ & $0.9(0.3-2.7)^{\star}$ \\
\hline CRP/IL-6 ratiob & $0.8(0.07-21)$ & $2.7(0.1-17)^{\star}$ \\
\hline S-Alb $(m g / d l)^{a}$ & $3.6 \pm 0.1$ & $4.6 \pm 0.1^{*}$ \\
\hline Time on HD (years) ${ }^{a}$ & $5 \pm 3$ & - \\
\hline
\end{tabular}

Table 2. Clinical and dialysis characteristics of the patients according to HCV serology.

\begin{tabular}{|c|c|c|}
\hline & $\mathrm{HCV}+(\mathrm{N}=62)$ & HCV- $(\mathrm{N}=56)$ \\
\hline Age (years) ${ }^{\mathrm{a}}$ & $45 \pm 11$ & $49 \pm 15$ \\
\hline Prevalence of males (\%) & 48 & 47 \\
\hline Time on HD (years) & $6 \pm 3$ & $4 \pm 2^{*}$ \\
\hline S-Alb $(m g / d l)^{a}$ & $3.5 \pm 0.4$ & $3.5 \pm 0.3$ \\
\hline $\operatorname{ALT}(I U / I)^{a}$ & $30 \pm 21$ & $20 \pm 24^{*}$ \\
\hline $\mathrm{hsCRP}(\mathrm{mg} / \mathrm{l})^{\mathrm{b}}$ & $6.6(0.2-62)$ & $11.8(0.3-150)$ \\
\hline IL-6 $(\mathrm{pg} / \mathrm{ml})^{\mathrm{b}}$ & $4.7(0.9-19)$ & $4.2(0.98-19.64)$ \\
\hline hsCRP/IL-6 ratio & $0.7(0.07-4.2)$ & $0.9(0.1-21)^{\star}$ \\
\hline
\end{tabular}


Figure 1. hsCRP/IL-6 ratio in $\mathrm{HCV}+$ and HCV- patients and healthy controls. The horizontal lines in the box plots represent the medians. For abbreviations, see legend to Tables 1 or 2. group, but this difference was not statistically significant $(P=0.08)$. There was no difference in IL-6 levels between the $\mathrm{HCV}+$ and HCV-groups, but the mean hsCRP/IL6 ratio was significantly lower in the $\mathrm{HCV}+$ group $(0.9 \pm 0.8$ vs $1.8 \pm 3.2, \mathrm{P}<0.05$; Figure 1). Significant correlations were found between log-hsCRP and log-IL-6 in $\mathrm{HCV}+$ $\left(\mathrm{r}^{2}=0.26, \mathrm{P}<0.0001\right)$ and $\mathrm{HCV}$ - patients $\left(r^{2}=0.27, \mathrm{P}<0.0001 ;\right.$ Figure 2).

\section{Discussion}

Although we could not demonstrate any difference in hsCRP or IL-6 levels between $\mathrm{HCV}+$ and $\mathrm{HCV}$ - patients, $\mathrm{HCV}+$ patients tended to have lower CRP levels in relation to IL-6 levels than the HCV-patients and the hsCRP/IL-6 ratio was lower in $\mathrm{HCV}+$ patients. The observed difference could imply that the liver response to IL-6 stimulation may be mitigated by the presence of $\mathrm{HCV}$. Therefore, we may speculate that the hepatic
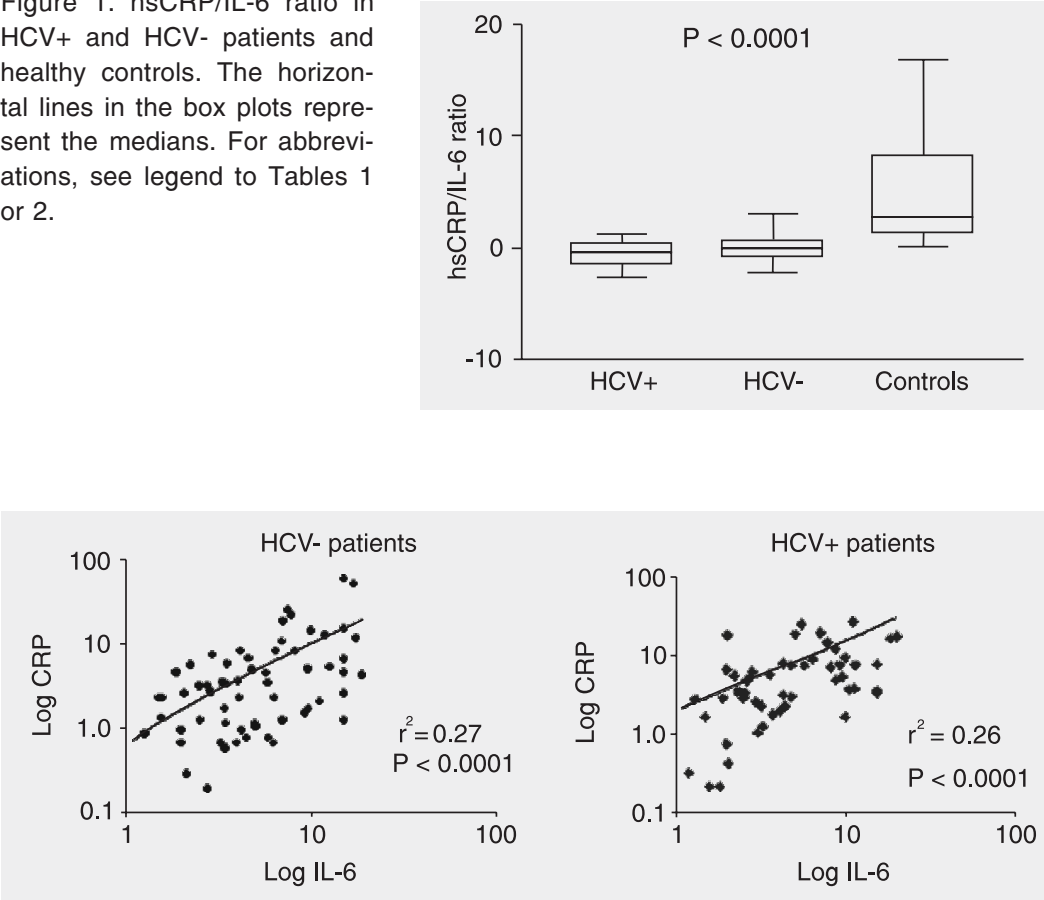

Figure 2. Correlation between serum high sensitivity $\mathrm{C}$-reactive protein (CRP), and interleukin 6 (IL-6) in $\mathrm{HCV}+$ and HCV-patients. The correlation coefficients were calculated by univariate regression analysis. injury caused by HCV could promote a disturbance in the production of CRP.

A decline in the release of acute phase reactants by the liver is observed postoperatively in non-uremic elderly patients undergoing major abdominal surgery (16). In these patients the decreased release of liver-synthesized acute phase reactants was associated with an impairment of hepatocyte function. In the present study, $\mathrm{HCV}+$ patients tended to have lower hsCRP levels compared to $\mathrm{HCV}$ - patients. This finding agrees with several lines of evidence previously reported in the literature. Stevens et al. (17) showed that CRP levels were significantly higher in $\mathrm{HCV}$ - patients compared to $\mathrm{HCV}+$ patients. Shima et al. (18) compared the expression of CRP by immunohistochemical analysis in $\mathrm{HCV}+$ patients and in patients with hepatitis $\mathrm{B}$ and concluded that the intensity of CRP expression in patients with hepatitis B was closely associated with the progression of the disease but this finding was not reproduced in $\mathrm{HCV}+$ patients. Finally, Lin et al. (19) evaluated non-uremic cirrhotic patients regarding the elevation of CRP in response to bacterial infection and showed that a higher CRP cut-off value had to be applied to detect these episodes. In the present study, the presence of a significant difference in the hsCRP/IL-6 ratio in $\mathrm{HCV}+$ patients might indicate that hepatocellular injury could affect CRP production in HCV+ HD patients, although no difference in IL-6 levels could be detected between $\mathrm{HCV}+$ and $\mathrm{HCV}$ - patients.

It remains controversial whether alterations in Th cell subpopulations contribute to the pathogenesis and clinical characteristics of chronic hepatitis C (20). Th1 and Th2 cells are involved in the response to various stimuli, such as infection, CKD and HD itself (21). More recently, it has been debated if a shift in the balance between the Th2 and Th1 immune responses may play a role in the progress of chronic hepatitis $(15,22)$. Recently, in a study on non-renal $\mathrm{HCV}+$ and $\mathrm{HCV}$ - patients with Sjögren syndrome, an 
imbalance of the Th1/Th2 ratio was shown in the HCV+ group (23). The same study demonstrated a predominant Th2 pattern with higher circulating levels of IL-6, IL-10 and TNF- $\alpha$ in $\mathrm{HCV}+$ patients compared to $\mathrm{HCV}$ - patients, possibly reflecting a more active systemic inflammatory response. On the other hand, modifications in the Th1/Th2 ratio provoked by ribavirin treatment leading to an imbalance towards the Th1 response may be associated with a more favorable outcome regarding HCV therapy (24-26).

The complexity of the cytokine profile in the HD population appears to be more intricate if we take into account that, besides the presence of $\mathrm{HCV}$, both HD treatment per se and CKD might interfere with the balance between Th1 and Th2. In patients with CKD, there is an increased body of evidence indicating a predominance of the Th1 response $(14,27)$. However, Spanakis et al. (22), in a study of the cytokine expression profile in $\mathrm{HCV}+$ compared with HCV- HD patients, found that the virus provoked an induced Th2 immunosuppression, and both Th1 and Th2 were related to a progressive state of $\mathrm{HCV}$ chronicity. On the other hand, Rostaing et al. (28), using the cytokine flow cytometry assay, demonstrated no impairment in the production of cytokines in $\mathrm{HCV}+$ dialysis patients. It seems difficult to establish if an imbalance in IL- 6 production could have an influence on the production of CRP in the liver. In the present study, we did not detect a significant difference in IL-6 production between the $\mathrm{HCV}+$ and $\mathrm{HCV}$ - groups. How- ever, the significant differences in the hsCRP/ IL-6 ratio according to HCV serology may imply that the local production of CRP might be impaired by the presence of HCV. Thus, based on these reports, it seems reasonable to propose that further studies are necessary to establish the complex mechanisms of the Th1 and Th2 response in the HCV uremic population.

Some limitations of the current study should be considered. First, the diagnosis of $\mathrm{HCV}$ infection was based on an indirect test and the presence of antibodies anti-HCVwith HCV RNA+ is not rare in HD patients (29). Second, the measurement of soluble receptor IL-6 might have been helpful as an indirect marker of cell hepatic responsiveness to IL- 6 and therefore of hsCRP expression. Third, the patients were characterized with only one measurement of IL-6 and hsCRP. Finally, histological evaluation by liver biopsy might have better characterized the extension of liver injury and its association with HCV serology.

The finding that the hsCRP/IL- 6 ratio was lower in $\mathrm{HCV}+$ patients than in $\mathrm{HCV}$ patients could indicate that hsCRP may be a less useful marker of inflammation in $\mathrm{HCV}+$ patients. Due to a high prevalence of $\mathrm{HCV}$ throughout the world in HD clinics, another hsCRP cut-off level for clinically significant inflammation might be needed for dialysis patients with chronic hepatitis C. Further studies are necessary to determine whether the presence of $\mathrm{HCV}$ infection influences CRP levels in HD patients.

\section{References}

1. Fabrizi F, Poordad FF \& Martin P (2002). Hepatitis C infection and the patient with end-stage renal disease. Hepatology, 36: 3-10.

2. Hinrichsen H, Leimenstoll G, Stegen G, Schrader H, Folsch UR \& Schmidt WE (2002). Prevalence and risk factors of hepatitis $C$ virus infection in haemodialysis patients: a multicentre study in 2796 patients. Gut, 51: 429-433.

3. Carneiro MA, Martins RM, Teles SA, Silva SA, Lopes CL, Cardoso DD, Vanderborght BO \& Yoshida CF (2001). Hepatitis C preva- lence and risk factors in hemodialysis patients in Central Brazil: a survey by polymerase chain reaction and serological methods. Memórias do Instituto Oswaldo Cruz, 96: 765-769.

4. Gershon AS, Margulies M, Gorczynski RM \& Heathcote EJ (2000). Serum cytokine values and fatigue in chronic hepatitis $C$ infection. Journal of Viral Hepatitis, 7: 397-402.

5. Stenvinkel P, Heimburger O, Paultre F, Diczfalusy $U$, Wang $T$, Berglund L \& Jogestrand T (1999). Strong association between 
malnutrition, inflammation, and atherosclerosis in chronic renal failure. Kidney International, 55: 1899-1911.

6. Yeun JY, Levine RA, Mantadilok V \& Kaysen GA (2000). Creactive protein predicts all-cause and cardiovascular mortality in hemodialysis patients. American Journal of Kidney Diseases, 35: 469-476.

7. Hurlimann J, Thorbecke GJ \& Hochwald GM (1966). The liver as the site of C-reactive protein formation. Journal of Experimental Medicine, 123: 365-378.

8. Arici M \& Walls J (2001). End-stage renal disease, atherosclerosis, and cardiovascular mortality: is C-reactive protein the missing link? Kidney International, 59: 407-414.

9. Paysant J, Blanque R, Vasse M, Soria C, Soria J \& Gardner CR (2000). Factors influencing the effect of the soluble IL-6 receptor on IL-6 responses in HepG2 hepatocytes. Cytokine, 12: 774-779.

10. Ishihara $K$ \& Hirano $T$ (2002). Molecular basis of the cell specificity of cytokine action. Biochimica et Biophysica Acta, 1592: 281-296.

11. Giannitrapani L, Cervello M, Soresi M, Notarbartolo M, La Rosa M, Virruso L, D'Alessandro N \& Montalto G (2002). Circulating IL-6 and sIL-6R in patients with hepatocellular carcinoma. Annals of the New York Academy of Sciences, 963: 46-52.

12. Stenvinkel $P$, Barany $P$, Heimburger $O$, Pecoits-Filho R \& Lindholm B (2002). Mortality, malnutrition, and atherosclerosis in ESRD: What is the role of interleukin-6? Kidney International, 61 (Suppl 80): 103-108.

13. Pecoits-Filho $R$, Barany $P$, Lindholm $B$, Heimburger $O$ \& Stenvinkel $P$ (2002). Interleukin-6 is an independent predictor of mortality in patients starting dialysis treatment. Nephrology, Dialysis, Transplantation, 17: 1684-1688.

14. Nitta K, Akiba T, Kawashima A, Kimata N, Miwa N, Nishida E, Uchida K, Honda K, Yumura W \& Nihei H (2002). Characterization of TH1/TH2 profile in uremic patients. Nephron, 91: 492-495.

15. Sobue S, Nomura T, Ishikawa $T$, Ito $S$, Saso K, Ohara H, Joh $T$, Itoh M \& Kakumu S (2001). Th1/Th2 cytokine profiles and their relationship to clinical features in patients with chronic hepatitis $\mathrm{C}$ virus infection. Journal of Gastroenterology, 36: 544-551.

16. Suttner SW, Surder C, Lang K, Piper SN, Kumle B \& Boldt J (2001). Does age affect liver function and the hepatic acute phase response after major abdominal surgery? Intensive Care Medicine, 27: 1762-1769.

17. Stevens LA, Adhirkala P, Kaysen G \& Levin NW (2002). The impact of $\mathrm{HCV}$ positive status on mortality and CRP levels in incident hemodialysis patients. Journal of the American Society of Nephrology, 13: 223 (Abstract).

18. Shima M, Nakao K, Kato Y, Nakata K, Ishii N \& Nagataki S (1996). Comparative study of $\mathrm{C}$-reactive protein in chronic hepatitis $\mathrm{B}$ and chronic hepatitis C. Tohoku Journal of Experimental Medicine,
178: 287-297.

19. Lin ZY, Chuang WL, Dai CY, Yu ML, Chen SC, Hsieh MY, Wang LY, Tsai JF \& Chang WY (2002). Clinical application of serum Creactive protein measurement in the detection of bacterial infection in patients with liver cirrhosis. Kaohsiung Journal of Medical Sciences, 18: 121-126.

20. Masaki N, Fukushima S \& Hayashi S (2002). Lower th-1/th-2 ratio before interferon therapy may favor long-term virological responses in patients with chronic hepatitis C. Digestive Diseases and Sciences, 47: 2163-2169.

21. Cribier B, Schmitt C, Rey D, Lang JM, Kirn A \& Stoll-Keller F (1998). Production of cytokines in patients infected by hepatitis $C$ virus. Journal of Medical Virology, 55: 89-91.

22. Spanakis NE, Garinis GA, Alexopoulos EC, Patrinos GP, Menounos PG, Sklavounou A, Manolis EN, Gorgoulis VG \& Valis D (2002). Cytokine serum levels in patients with chronic HCV infection. Journal of Clinical Laboratory Analysis, 16: 40-46

23. Ramos-Casals M, Garcia-Carrasco M, Cervera R, Filella X, Trejo O, de la Red G, Gil V, Sanchez-Tapias JM, Font J \& Ingelmo M (2002). Th1/Th2 cytokine imbalance in patients with Sjogren syndrome secondary to hepatitis $\mathrm{C}$ virus infection. Seminars in Arthritis and Rheumatism, 32: 56-63.

24. Amati L, Caradonna L, Magrone T, Mastronardi ML, Cuppone R, Cozzolongo R, Manghisi OG, Caccavo D, Amoroso A \& Jirillo $E$ (2002). Modifications of the immune responsiveness in patients with hepatitis $\mathrm{C}$ virus infection following treatment with IFN-alpha/ ribavirin. Current Pharmaceutical Design, 8: 981-993.

25. Hultgren C, Milich DR, Weiland O \& Sallberg M (1998). The antiviral compound ribavirin modulates the $T$ helper (Th) 1/Th2 subset balance in hepatitis B and $\mathrm{C}$ virus-specific immune responses. Journal of General Virology, 79 (Part 10): 2381-2391.

26. Ning Q, Brown D, Parodo J et al. (1998). Ribavirin inhibits viralinduced macrophage production of TNF, IL-1, the procoagulant fgl2 prothrombinase and preserves Th1 cytokine production but inhibits Th2 cytokine response. Journal of Immunology, 160: 3487-3493.

27. Heine G, Sester U, Sester M, Scherberich JE, Girndt M \& Kohler H (2002). A shift in the $\mathrm{Th}(1) / \mathrm{Th}(2)$ ratio accompanies the clinical remission of systemic lupus erythematosus in patients with endstage renal disease. Nephrology, Dialysis, Transplantation, 17: 1790-1794.

28. Rostaing L, Borde JS, Hasle C, Bories P, Allal A, Abbal M \& Durand D (2001). Lack of effect of chronic hepatitis C virus infection on T-cell cytokine production in chronic hemodialysis patients. American Journal of Nephrology, 21: 194-199.

29. Pawlotsky JM (2002). Use and interpretation of virological tests for hepatitis C. Hepatology, 36: S65-S73. 